\title{
A STUDY OF AFFECTING FACTORS ON THE DEGREE OF UNIVERSITY STUDENTS LOYALTY TO THE BRAND OF NIKE
}

\author{
A. S. Hazhbar al-Sadati ${ }^{1 *}$, J. Jeavik ${ }^{2}$, Z. Behbahani ${ }^{3}$, M. Khabiri ${ }^{4}$ \\ ${ }^{1}$ MA student of Marketing Management in Sports, Tehran University, Iran \\ ${ }^{2}$ MA student, Ferdowsi University of Mashhad, Iran \\ ${ }^{3} \mathrm{PhD}$ student in Cultural Management and Programming, Islamic Azad University, Science and \\ Research Branch, Tehran, Iran \\ ${ }^{4}$ Associate Professor in Sports Management, University of Tehran, Iran
}

Published online: 16 July 2016

\begin{abstract}
There are different factors which affect the way people select and continue their attitudes towards products of certain brands. The main objective of the present study was investigating factors affecting the degree of University students' loyalty to Nike brand. This research is functional in regard with objective and descriptive-temporary in terms of kind; it was conducted among BA, MA, and PhD student of Physical Education in Tehran University with a sample size of 248 subjects. Researcher-constructed questionnaire, which examined three influential factors (trust, purchase intent, brand image), on the loyalty of University Students, was used to collect data. Research data was analyzed using EM algorithm and Spss software and stepwise multiple regression was applied to investigate the impact of variables on students' loyalty. Significant regression model showed that all three variables of trust, purchase intent, and brand image had significant effects.
\end{abstract}

\footnotetext{
Author Correspondence, e-mail: ahojabr@yahoo.com

doi: http://dx.doi.org/10.4314/jfas.v8i2s.102
} 
Brand trust was the most influential variable with regression coefficient of $0.740(p<0.001)$. Based on the results of the present study, the hierarchical priority of three variables, according to students' replies, was brand trust, purchase intent, and brand image. The results showed that brand trust had the first priority among variables and that Nike brand has managed, on the basis of quality, to satisfy various needs, intentions, and tasks of larger number of university students.

Key words: Nike brand, brand trusts, brand image, loyalty, purchase intent

\section{INTRODUCTION}

In an age of increasing globalization, competitiveness is a major issue among policymakers at different levels (national, industry, enterprise) in different parts of the world. Business strategies are planned in order for companies to strengthen and solidify their competitive position in the realms of national and global markets. Organizations function differently and integrate various unique strategies. World class companies use common features in order to improve competitiveness. A key factor behind the success of world class organizations is their ability and strategy in integrating activities to affects three domains of market, operation, and culture. Competitive advantage results from concerted efforts to generate distinction in market place, operation, and organizational culture. To reach this goal, brand equity is one of the most important marketing concepts which have come under investigation by academics and marketing researchers over the past decade. Important strategic rile of brand equity in achieving competitive advantage and strategic management decisions is a right reason for this reputation. When brand equity is accurately measured, it can function as a suitable criterion for evaluating long-term effects of marketing decisions (Simon and Sullivan 1993:22). Famous brand can determine the product benefits and cause greater public awareness in comparison with unpopular brand (Keller 2003). Brand plays an important role in initial purchase comparison, evaluation, and service companies. It seems that brands sell themselves in today's competitive world. Brand equity is classified in two categories in marketing literature; first, those which include customer perception, such as brand awareness, brand association, and perceived quality. Second, are those included in customer behavior, such as loyalty to brand and focus on price differences. Aaker is one of few researchers who combined perception and behavior phases. The main advantage of combining these two dimensions in a single yardstick of brand equity is that they are so welldefined that indicators are poor determinants of market behavior per se(Myers 2003:40). Brand 
image, among tangible aspects of a product, is the most important thing which attracts attention of most marketing strategies focused on highlighting the brand. Therefore, brand is one of the most precious assets through which companies can acquire a strategic advantage in trade (Javanmard and Soltanzade 2009:235). Companies should pay more attention to the influence of brand image on customer loyalty and subsequent profitability; they have understood the necessity of determining branding and marketing strategies according to unique characteristics and capacity to improve previous results (ibid 238). The researches show that brand image affects customer perception of product and service quality, and company's reputation is based on customers' perception and loyalty. Images of prestigious brands attract customer to purchase the item again and decreases the price of their behavior, judgment, and selection. (Bryan 2000:185199).

Loyalty of a consumer signifies the degree of his intention to purchase the item again. There has expanded researches on identifying factors which affect customer satisfaction and loyalty in recent years. In most cases, customer loyalty is vital to the success of business or organization because attracting new customers is usually more expensive than retaining existing ones (Sabzei et al 2014:74). Sports brand is an example of brands subject to the present research. The sports industry is one of the most important and attractive industries the products of which face strong competition in the world. Sports clothing is a crucial sports product with an important role in the implementation and development of sports. According to the results of different studies, sports clothing assigned $22 \%$ of the world's total cloth marketing in the early 2000 and increased gradually in the following years. Since sports clothing market occupies a considerable part of world's total cloth marketing, studying relate consumers will be extremely beneficial to producers and researchers of sports clothing (Lora 2001). Nike is an American multinational company which is active in the fields of designing, production, developing, and delivering products such as shoes, clothes, apparel, and sport accessories to the world's market. This company, with 24/1 billion dollars revenue in 2012 and employing more than 44000 workers around the world, is one of the few larger companies in the field of designing sports shoes, clothes, apparels, and sport accessories. The value of this company has been estimated as 10/7 billion dollars in 2010, labeling it as the best sports goods designer around the world. This company was founded in 1964 by Bill Bowerman and Phillip Knight under the name of Blue Ribbon Sports in America and the name was changed to Nike later on. Since German shoes, 
particularly Adidas, had dominated the shoe industry around the world, Bowerman and Knight decided to startup a company to import cheap shoes from Japan. They changed the name of their company to Nike, which is the Greek of of victory in 1977. Nike logo is one of the most famous logos in the world, known as 'JUST DO IT' in the world.

Nowadays, customer satisfaction is not enough per se and organizations and companies should not rely solely on it; they should ensure the point that their satisfied customers are loyal, as well. The purpose is to establish long-term relationship with the client in order to gain long-term benefits from them. So, companies put themselves in the shoes of their customers and try to understand their needs based on the requirements of the time so that their customers are thoroughly satisfied with them. In any organization, whether manufacturing or service, customers are the most important factor for survival. If the organization succeeds in attracting satisfaction and loyalty of customers, it has guaranteed long-term growth and survival for itself (Sabzei et al 2014:74). Customer loyalty is of strategic importance for any company so that enhancing customer loyalty has become a hot topic among managers, consultants, and academic scholars (Keningfam et al 2007:362). The importance of this issue is due to the fact that customers consider it in their decision about the goods and services. Organizations and institutions that are successful in building customer loyalty gain a major competitive advantage against their rivals (Akso 2006:187). Keller (2003) studies brand loyalty under the so-called 'brand resonance epithet' which returns to the nature and extent of customer-based relationships and the sense of harmony the customers feel with the products. True brand resonance signifies loyal customers who actively interact with the brand and share their experiences with others. Such a definition of brand loyalty demonstrates a direct relationship between brand loyalty and brand equity. (Aaker 1991:91)

Some studies have been done in this domain. Sweeney and Swait (2008), in a research entitled 'The impact of brand reputation on customer loyalty', concluded that the reputation of brand increases positive mouth to mouth feedback; so, brand reputation has positive effect on customer loyalty. Wong Foong Yee and Yahya Sidek (2008) indicated that there is a significant relationship between brand product quality, price, style, advertising, quality of service, and store environment with loyalty to apparel brand loyalty. Homburg and Giering (2001) showed that satisfaction with product, sales process, and post-selling services positively affects customer loyalty. 
Nowadays, domestic and foreign brands use unique features to stabilize their customers and enhance product durability. However, there are different factors in the selection of brand which could affect the continuation of and attitude towards products. It is observed that many sport products have a large audience; in other words, larger and famous organizations and institutions take action to purchase famous brands for their use to, hereby, prompt the reputation of their companies. Therefore, the present study has focused on such sports brand, especially Nike, and examined the factors which affect brand selection among university students.

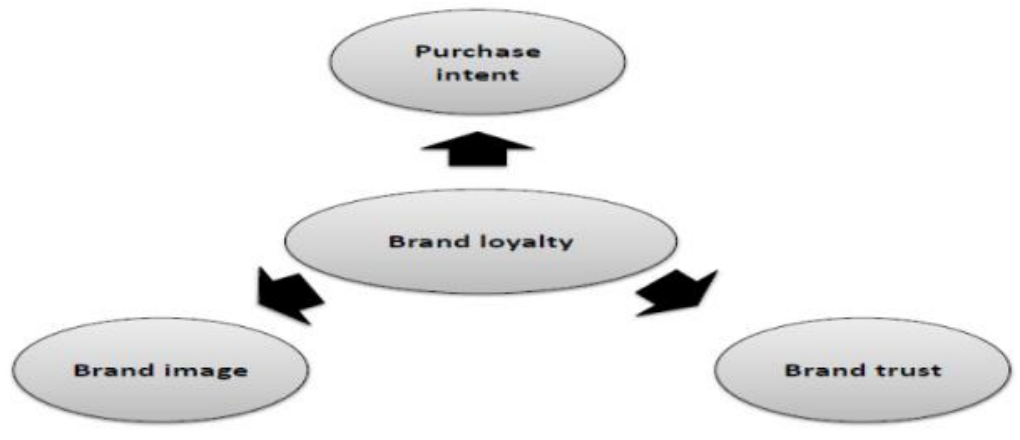

Fig.1. Conceptual model of the research

Source: taken from theoretical framework of the study; a combination of Oliver (2003), Keller (2003), Aaker (1991), and Javalgi and Moberg (1997) models

\section{RESEARCH METHOD}

The present study is, objectively speaking, a functional research and descriptive-survey in terms of data collection; library and filed studies in the faculty of Physical education of Tehran University were used in order to collect necessary data. The statistical population included 894 BA, MA, and PhD students of Tehran University, Faculty of Physical Education in 2015. According to Morgan formula, the sample size was calculated as 245. The questionnaire was confirmed by some professors of Physical education in order to ensure the validity of items. Reliability was measured by Cronbach's alpha coefficient and it was estimated as 95\%, which is indicative of optimal reliability. Researcher-constructed questionnaire, including 3 questions, 6 questions about brand intent, 4 questions about brand trust, 9 questions about brand image, and 4 questions about brand loyalty, was distributed among 250 participants; sample size was estimated 248 through simple random sampling distribution; so, 248 questionnaires were collected. E M algorithm and Spss software, version 19, were used to analyze collected data. 
The major objective of the present study was investigating factors affecting the degree of University students' loyalty to Nike brand. Four dimensions of Nike brand, brand intent, brand trust, and brand image as independent variables and Nike brand loyalty as dependent variable, were organized into a questionnaire.

\section{RESULTS AND FINDINGS OF THE RESEARCH}

The average of the participants was between 20-26 years old. There were 120 students with bachelor's degree, 110 students with master's degree, and $18 \mathrm{PhD}$ students of Tehran University. First, some data was eliminated during data screening because some items were left unanswered. Lost data was reconstructed using EM algorithm based on all items; then, stepwise multiple regression was used to investigate the effects of rand image, brand intent, and brand trust variables on brand loyalty.

Table 1. Summarized statistics obtained for the regression model to predict the loyalty to Nike brand

\begin{tabular}{|c|c|c|c|c|c|c|c|c|c|}
\hline \multirow[t]{2}{*}{ Model } & \multirow[t]{2}{*}{$\mathrm{R}$} & \multirow[t]{2}{*}{$\mathrm{R} 2$} & \multirow{2}{*}{$\begin{array}{l}\text { Modified } \\
\text { R2 }\end{array}$} & \multirow{2}{*}{$\begin{array}{l}\text { Estimated } \\
\text { standard } \\
\text { error }\end{array}$} & \multicolumn{5}{|c|}{ statistics } \\
\hline & & & & & $\mathrm{R} 2$ & $\mathrm{~F}$ & $\mathrm{Df}_{1}$ & $\mathrm{Df}_{2}$ & Sig \\
\hline 3 & $0 / 732$ & $0 / 537$ & $0 / 531$ & $2 / 28$ & $0 / 537$ & $94 / 92$ & 3 & 264 & $<0 / 001$ \\
\hline
\end{tabular}

As it can be seen in Table 1. A significant regression model is obtained. Therefore, the effect of all the three variables of (trust, purchase intent and image) on the loyalty to Nike is significant ( $\mathrm{P}$ $<0 / 0001 \mathrm{R} 2=0.531)$.

Table 2. Estimated parameters of the regression model to predict the Nike brand loyalty

\begin{tabular}{|c|c|c|c|c|c|c|c|}
\hline \multirow[t]{2}{*}{$\begin{array}{l}\text { Predictive } \\
\text { factors }\end{array}$} & \multicolumn{2}{|c|}{$\begin{array}{l}\text { Non-standardized } \\
\text { coefficients }\end{array}$} & \multirow{2}{*}{$\begin{array}{c}\text { Standardized } \\
\text { coefficients }\end{array}$} & \multirow[t]{2}{*}{$\mathrm{t}$} & \multirow[t]{2}{*}{ Sig } & \multicolumn{2}{|c|}{$\begin{array}{l}95 \% \text { confidence } \\
\text { interval }\end{array}$} \\
\hline & B & SE & & & & $\begin{array}{l}\text { Lower } \\
\text { bound }\end{array}$ & $\begin{array}{l}\text { upper } \\
\text { bound }\end{array}$ \\
\hline Fixed & $0 / 348$ & $0 / 790$ & & $0 / 440$ & $0 / 660$ & $-1 / 21$ & $1 / 90$ \\
\hline Image & $0 / 133$ & 0/041 & 0/195 & $3 / 24$ & $0 / 001$ & $0 / 052$ & $0 / 214$ \\
\hline Intention & $0 / 213$ & 0/059 & $0 / 238$ & $3 / 63$ & $<0 / 001$ & $0 / 097$ & $0 / 328$ \\
\hline Trust & $0 / 408$ & 0/080 & $0 / 386$ & $5 / 07$ & $<0 / 001$ & $0 / 250$ & $0 / 567$ \\
\hline
\end{tabular}


Considering Table 2 . Trust in brand $(8 / 40 \%)$ had the largest share in predicting brand loyalty factors. Brand intention (03/21\%) and finally the brand image $(3.13 \%)$ had the highest effect on brand loyalty to Nike, respectively. The remaining cases related to the variables that were not examined in this study $(24.6 \%)$.

(B) The results of the regression analysis separately for the three criterion variables

In this section the results of the regression analysis for all three criterion variables to the Nike brand loyalty will be discussed separately.

Table 3. Summarized statistics obtained for the regression model to predict the loyalty to Nike brand based on the variable of Image.

\begin{tabular}{|c|c|c|c|c|c|c|c|c|c|}
\hline \multirow[t]{2}{*}{ Model } & \multirow[t]{2}{*}{$\mathrm{R}$} & \multirow[t]{2}{*}{$\mathrm{R} 2$} & \multirow{2}{*}{$\begin{array}{c}\text { Modified } \\
\text { R2 }\end{array}$} & \multirow{2}{*}{$\begin{array}{l}\text { Estimated } \\
\text { standard } \\
\text { error }\end{array}$} & \multicolumn{5}{|c|}{ statistics } \\
\hline & & & & & $\mathrm{R} 2$ & $\mathrm{~F}$ & $\mathrm{Df}_{1}$ & $\mathrm{Df}_{2}$ & Sig \\
\hline 1 & $0 / 539$ & $0 / 351$ & $0 / 349$ & $2 / 68$ & $0 / 351$ & $134 / 26$ & 1 & 248 & $<0 / 001$ \\
\hline
\end{tabular}

As it can be seen in Table 3, regression model is significant. So, the effect of brand image on brand loyalty is significant.

Table 4. Estimated parameters of the regression model to predict the Nike brand loyalty based on the variable of Image.

\begin{tabular}{|c|c|c|c|c|c|c|c|}
\hline \multirow[t]{2}{*}{$\begin{array}{l}\text { Predictive } \\
\text { factors }\end{array}$} & \multicolumn{2}{|c|}{$\begin{array}{l}\text { Non-standardized } \\
\text { coefficients }\end{array}$} & \multirow{2}{*}{$\begin{array}{l}\text { Standardized } \\
\text { coefficients } \\
\text { Beta }\end{array}$} & \multirow[t]{2}{*}{$\mathrm{t}$} & \multirow[t]{2}{*}{ Sig } & \multirow{2}{*}{$\begin{array}{l}95 \% \\
\text { interval } \\
\text { Lower } \\
\text { bound }\end{array}$} & \multirow{2}{*}{$\begin{array}{l}\text { confidence } \\
\text { upper } \\
\text { bound }\end{array}$} \\
\hline & B & SE & & & & & \\
\hline Fixed & $1 / 19$ & $0 / 865$ & & $1 / 38$ & $0 / 169$ & $-0 / 510$ & $2 / 89$ \\
\hline Image & $0 / 404$ & 0/035 & 0/539 & $11 / 58$ & $<0 / 001$ & $0 / 336$ & $0 / 473$ \\
\hline
\end{tabular}

According to the Table 4, brand image variable with regression coefficient of 404/0 could significantly be used to predict the criterion variable $(\mathrm{p}<0 / 0001)$. 
Table 5. Summarized statistics obtained for the regression model to predict the loyalty to Nike brand based on the variable of Intention.

\begin{tabular}{ccccccccc}
\hline $\mathrm{R}$ & $\mathrm{R} 2$ & Modified & Estimated & \multicolumn{5}{c}{ statistics } \\
\cline { 8 - 10 } & & $\mathrm{R} 2$ & $\begin{array}{c}\text { standard } \\
\text { error }\end{array}$ & $\mathrm{R} 2$ & $\mathrm{~F}$ & $\mathrm{Df}_{1}$ & $\mathrm{Df}_{2}$ & $\mathrm{Sig}$ \\
\hline $0 / 634$ & $0 / 402$ & $0 / 400$ & $2 / 57$ & $0 / 402$ & $166 / 97$ & 1 & 248 & $<0 / 001$ \\
\hline
\end{tabular}

As it can be seen in Table 5, regression model is significant. So, the effect of brand intention on brand loyalty is significant.

Table 6. Estimated parameters of the regression model to predict the Nike brand loyalty based on the variable of Image.

\begin{tabular}{|c|c|c|c|c|c|c|c|}
\hline \multirow[t]{2}{*}{$\begin{array}{l}\text { Predictive } \\
\text { factors }\end{array}$} & \multicolumn{2}{|c|}{$\begin{array}{l}\text { Non-standardized } \\
\text { coefficients }\end{array}$} & \multirow{2}{*}{$\begin{array}{l}\begin{array}{l}\text { Standardized } \\
\text { coefficients }\end{array} \\
\text { Beta }\end{array}$} & \multirow[t]{2}{*}{$\mathrm{t}$} & \multirow[t]{2}{*}{ Sig } & \multirow{2}{*}{$\begin{array}{l}95 \% \\
\text { interval } \\
\text { Lower } \\
\text { bound }\end{array}$} & \multirow{2}{*}{$\begin{array}{l}\text { confidence } \\
\text { upper } \\
\text { bound }\end{array}$} \\
\hline & B & SE & & & & & \\
\hline Fixed & $2 / 62$ & $0 / 670$ & & $3 / 90$ & $<0 / 001$ & $1 / 29$ & $3 / 94$ \\
\hline Image & $0 / 566$ & $0 / 044$ & $0 / 634$ & $12 / 92$ & $<0 / 001$ & $0 / 480$ & $0 / 653$ \\
\hline
\end{tabular}

According to the Table 6 , brand intention variable with regression coefficient of $0 / 566$ could significantly be used to predict the criterion variable $(\mathrm{p}<0 / 0001)$.

Table 7. Summarized statistics obtained for the regression model to predict the loyalty to Nike brand based on the variable of Trust.

\begin{tabular}{ccccccccc}
\hline $\mathrm{R}$ & $\mathrm{R} 2$ & Modified & Estimated & \multicolumn{5}{c}{ statistics } \\
\cline { 8 - 10 } & & $\mathrm{R} 2$ & standard & $\mathrm{R} 2$ & $\mathrm{~F}$ & $\mathrm{Df}_{1}$ & $\mathrm{Df}_{2}$ & $\mathrm{Sig}$ \\
\hline $0 / 699$ & $0 / 489$ & $0 / 487$ & $2 / 38$ & $0 / 489$ & $237 / 21$ & 1 & 248 & $<0 / 001$ \\
\hline
\end{tabular}

As it can be seen in Table 7, regression model is significant. So, the effect of brand trust on brand loyalty is significant. 
Table 8. Estimated parameters of the regression model to predict the Nike brand loyaltybased on the variable of Trust.

\begin{tabular}{|c|c|c|c|c|c|c|c|}
\hline \multirow[t]{2}{*}{$\begin{array}{l}\text { Predictive } \\
\text { factors }\end{array}$} & \multicolumn{2}{|c|}{$\begin{array}{l}\text { Non-standardized } \\
\text { coefficients }\end{array}$} & \multirow{2}{*}{$\begin{array}{c}\text { Standardized } \\
\text { coefficients } \\
\text { Beta }\end{array}$} & \multirow[t]{2}{*}{$\mathrm{t}$} & \multirow[t]{2}{*}{ Sig } & \multicolumn{2}{|c|}{$\begin{array}{l}\text { 95\% confidence } \\
\text { interval }\end{array}$} \\
\hline & B & SE & & & & $\begin{array}{l}\text { Lower } \\
\text { bound }\end{array}$ & $\begin{array}{l}\text { upper } \\
\text { bound }\end{array}$ \\
\hline Fixed & $3 / 26$ & $0 / 525$ & & $6 / 214$ & $<0 / 001$ & $2 / 23$ & $4 / 30$ \\
\hline Image & $0 / 740$ & $0 / 048$ & 0/699 & $15 / 402$ & $<0 / 001$ & $0 / 646$ & $0 / 835$ \\
\hline
\end{tabular}

According to the Table 4, brand trust variable with regression coefficient of $0 / 740$ could significantly be used to predict the criterion variable $(\mathrm{p}<0 / 0001)$.

\section{DISCUSSION AND CONCLUSION}

Strong brand name increases customer confidence in buying intangible products and enables customers to visualize and understand intangible products better. The present study investigated the effects of brand image, brand trusts, and purchase intent on Nike brand loyalty. The results show that Nike brand is of high trust among Physical education students of Tehran University.

Table 9. Research variables ranking

\begin{tabular}{cc}
\hline Research variable & Value and rank \\
\hline Trust & 0.408, first \\
\hline Intent & 0.213, second \\
\hline Image & 0.133, third \\
\hline
\end{tabular}

Based on research variables represented in Table9, Nike brand trust comes in the first rank while intent and brand image come in the second and third rank. Based on the studies of Javalgi and Moberg (1997), brand loyalty is defined in association with behavior, attitude, and selection perspectives and, as perspectives of students showed, loyalty to Nike brand roots in their trust in the product.

$57 / 2 \%$ participants believe that their trust in Nike brand products comes from the guarantee given to them due to their satisfaction; this is consistent with Oliver's model. Based on the studies of Homburg and Giering (2001), satisfaction with products has positive influence on 
customer loyalty. Thus, based on Helier et al model, preferring a brand will result in purchasing it.

Expectations and needs of 52\% of participants of Nike brand products have been met, which is consistent with the results of Haji Karimi and Jalalzade (2008) about positive role of considering customer needs and expectations in establishing commitment and loyalty among potential customers.

Based on the results of the present study, brand trust was associated with following items of questionnaire in order: quality of the product, satisfaction of the customer, and observing different tastes and needs. Based on conducted researches, high quality products can guarantee survival of items through ensuring customers, stabilizing quality, and promoting it or preventing its decline. Quality of the product might be of paramount importance in the first place and profits shall be sacrificed to quality, because high quality can guarantee purchasing the item, attracting new customers, and improving financial situation of the company over time.

\section{REFERENCES}

1. Haji Karimi, Abbas Ali. "Factors Affecting Customer Loyalty to a Brand". Management Message. 2008, 15.

2. Sabzei, Ali Reza. Husseini, Ali. Bandar Khani, Mehdi. (2014). "Investigating Factors Influential on Customer Loyalty; Case study: Agricultural Bank”. Industrial Management Journal of Faculty of Humanities, Sanandaj Islamic Azad University. $9^{\text {th }}$ year, special Management and accounting Issue.

3. Soltanzade, Ali Akbar. Javanmard, Habibolah. "Investigating Internet and Website Brands and their Impacts on Customer Loyalty and Trust”. Business Quarterly. 2009, 53.

4. A.Myers, "Managing brand equity: a look at the impact of attributes", Journal of Product \& Brand Management, 2003, 12(1): 39-51.

5. Aaker, D.A. (1991)- Managing Brand Equity, The Free Press, New York, NY.

6. as moderators of realtionship between customer satisfaction and loyalty _An empirical analysis". Psychology and marketing. Vol. 18.PP:43-66.

7. Brian, D. Foster, John. W. Cadogan. "Relationship selling and customer loyalty: an empirical invesitgation". Marketing intelligence and planning". 2000, 18(4): 185-199.

8. Homburg, Christian. Giering, annaette (2001). "Personal characteristics 
9. Keller, K.L. (2003) Strategic Brand Management: Building, Measuring and Managing Brand Equity, 2nd ed., Prentice-Hall, Englewood Cliffs, NJ.

10. Lora, S., Cowie, B. S. (2001). "Relationship between male cyclists' sport clothing involvement sport clothing interests and commitment to cycling”. Thesis (M.S)Ohio state university.

11. Simon, C.J. and Sullivan, M.W. "The measurement and determinants of brand equity: a financial approach", Marketing Science, 1993, 12(1): 28-53.

12. Sportswear”. Int. Journal of economics and management, 2 (2). PP: 221-236.

13. Sweeney, J., and Swait , J. The effect of brand credibility. Journal of Retailing and Consumer Service, 2008, 15: 179-193. http://www.shikbrand.com.

14. Wong, Foong, Yee. Yahyah Sidek. "Influence of brand loyalty on consumer sportswear". Int. Journal of economics and management, 2008, 2 (2):221-236.

How to cite this article:

Hazhbar al-Sadati A S, Jeavik J, Behbahani Z, Khabiri M. A study of affecting factors on the degree of university students loyalty to the brand of nike. J. Fundam. Appl. Sci., 2016, $8(2 S)$, 1619-1629. 